\title{
PERLINDUNGAN MOTIF BATIK MILIK PENGRAJIN PERORANGAN DI BOJONEGORO MENURUT UNDANG-UNDANG NO. 19 TAHUN 2002 TENTANG HAK CIPTA DAN FATWA MUI (STUDI KASUS DI SENTRA PENGRAJIN BATIK JENEGOROAN) \\ Hidayatul Nikmah \\ Fakultas Syari'ah UIN Maulana Malik Ibrahim Malang \\ Email: idaarekbojonegoro@gmail.com
}

\begin{abstract}
ABSTRAK
This research indicates that there is protection of batik in Bojonegoro regency, that is batik craftsmen have to register to Disperindag Bojonegoro regency as a temporary protection. The regulation number 19 of 2002 about Copyright and recognized by law is registering djhki according to article 37 act no. 192002 on copyright.Form copyright protection a batik reviewed in mui fatwa was appertain hak milik huquq milkiyyah one property right huquq maliyyah.Batik is category mal or possessions because mal jointed on two principle namely ainiyah and urf batik is included in the category ainiyah because it is category objects or property intangible. So that obtains legal protection.On mui fatwa use copyright another without permission of a creator is his legal common and is liable compensation is categorized theft.On act.No. 19 year 2002 on copyright $b$
\end{abstract}

Hasil penelitian ini menunjukkan bahwa bentuk perlindungan motif batik dari Pemerintah Kabupaten Bojonegoro yaitu mendata, menghimbau para pengrajin batik untuk mendaftarkan ke Disprindag Kab, Bojonegoro sebagai bentuk perlindungan sementara. Pada UU. No. 19 Tahun 2002 Tentang Hak Cipta perlindungan yang resmi dan diakui oleh hukum adalah mendaftarkan ke DJHKI sesuai pasal 37 UU No. 19 Tahun 2002 Tentang Hak Cipta. Bentuk perlindungan hak cipta motif batik ditinjau dalam Fatwa MUI merupakan tergolong hak milik huquq milkiyyah salah satu hak kekayaan huquqmâliyyah. Batik merupakan kategori mâl atau harta karena mâl bersendi pada dua asas yaitu 'ainiyah dan'urf batik merupakan masuk dalam kategori 'ainiyah karena merupakan kategori benda atau harta yang berwujud. sehingga memperoleh perlindungan hukum. Pada Fatwa MUI menggunakan hak cipta orang lain tanpa izin dari pencipta adalah hukumnya haram dan bisa dikenakan ganti rugi termasuk kategori pencurian. Pada UU. No. 19 Tahun 2002 Tentang Hak Cipta bahwa hak cipta melindungi hak moral dan hak ekonomi yang hukumannya telah diatur dalam pasal 72 UU. No. 19 Tahun 2002 Tentang Hak Cipta.

Kata Kunci : Hak Cipta, Hukum Islam, Batik Jonegoroan, Huquq Mâliyyah, Huquq Milkiyyah, Harta.

Batik Jenegoroan muncul karena Industri Kecil Menengah (IKM) diyakini memiliki nilai strategis dalam perekonomian nasional dan peningkatan PDRB dan Industri Kecil Menengah merupakan bagian dari sandaran pembangunan ekonomi nasional.
Pemerintah Kab. Bojonegoro terkait perlindungan motif batik bahwa pemerintah kab. Bojonegoro di sini memberikan perlindungan dengan membuka atau memberi anjuran untuk mendaftarkan ke Disprindag Kab. Bojonegoro sebagai salah satu bentuk 
perlindungan yang diberikan pengrajin batik terkait motif batik milik pengrajin perorangan. Pemkab Bojonegoro memberi perlindungan ini bahwa pemerintah sendiri pernah menerima laporan terkait pengrajin batik yang mencoba mencontoh motif batik milik pengrajin perorangan, dengan laporan tersebut pemerintah menindak lanjuti dengan datang dan membuktikan terkait laporan pencontohan motif batik milik pengrajin perorangan di sini pemerintah menegur dan ketika teguran telah dilakukan dan tidak di hiraukan maka tindakan selanjutnya adalah pencabutan izin usaha. Akan tetapi perlindungan dari Pemkab. Bojonegoro ini hanya sebatas itu saja, perlindungan yang sebenarnya pada hak cipta adalah pendaftaran ke DJHKI yang

dimana pendaftaran ke DJHKI ini merupakan pendaftaran hak cipta yang resmi dan diakui oleh hukum.

Fatwa MUI Nomor :1/ MUNASVII/ MUI/15/2005 menetapkan fat-wa tentang perlindungan Hak Kekayaan In-telektual (HKI) bahwa dalam fatwa ini, yang dimaksud dengan kekayaan intelektual adalah kekayaan yang timbul dari hasil olah pikir otak yang menghasilkan suatu produk atau proses yang berguna untuk manusia dan diakui oleh negara berdasarkan peraturan perundang-undangan yang berlaku yang di mana pada Islam terdapat larangan memakai dan memanfaatkan hak orang lain sebagaimana pada Al-Qur'an Surat Al-Baqarah ayat 188 yang artinya :

” janganlah sebagaimana kamu memakan harta sebagian yang lain dengan jalan yang batil. ",

Ayat di atas mengingatkan umat Islam agar tidak memakai atau menggunakan hak orang lain dan tidak pula memakan harta orang lain, kecuali dengan persetujuan pemilik. $^{2}$

Alasan penulis mengambil judul ini karena motif batik di Bojonegoro ini terkait motif batik adalah karena batik merupakan salah satu ciptaan yang di lindungi oleh Undang-Undang

\footnotetext{
${ }^{1}$ Qs. Al-Baqarah:118

${ }^{2}$ Masjfuk, Masail Fiqhiyah Kapita Selekta Hukum Islam. Edisi I. Cet I. Jakarta: CV. Haji Masagung, 1994, h. 214.
}

No. 19 Tahun 2002 Tentang Hak Cipta dan Fatwa MUI merupakan hukum Islam yang juga membahas terkait Hak Kekayaan Intelektual yaitu salah satu dari hak Cipta yang dimana Fatwa MUI bahwa hak cipta merupakan hak milik dan juga hak kekayaan yang didalam nya terdapat harta yang bisa memperoleh perlindungan hukum.

Menurut W.R.Cornish, hak milik intelektual melindungi pemakaian ide dan informasi yang mempunyai nilai komersil atau nilai ekonomi. ${ }^{3}$ Menurut Ismail Saleh, Intelectual Property Rights dapat diterjemahkan sebagai hak kepemilikan intelektual, menyangkut hak cipta (copyrights) dan hak milik perindustrian (industrial property rights). ${ }^{4}$ Hak Kekayaan Intelektual (HKI) atau Intellectual Property Rights (IPRs) merupakan hak ekonomi yang diberikan oleh hukum kepada seorang pencipta atau penemu atas suatu hasil karya dari kemampuan intelektual manusia. ${ }^{5}$ manfaat HKI bagi negara Indonesia. Ada beberapa manfaat yang diperoleh dari suatu sistem HKI yang baik, yaitu: ${ }^{6}$

- HKI dapat meningkatkan pertumbuhan perdagangan dan investasi sebuah negara;

- HKI dapat mengembangkan dan meningkatkan teknologi;

- HKI mampu mendorong perusahaan dapat bersaing secara global;

- HKI dapat membantu meningkatkan inovasi inventoran secara efektif;

- HKI dapat mengembangkan sosial budaya masyarakat;

(a) HKI dapat menjaga reputasi perusahaan di dunia internasional untuk kepentingan ekspor.

\footnotetext{
${ }^{3}$ Etty Susilowati, "Kontrak Alih Teknologi pada Industri Manufaktur" (Yogyakarta: Genta Press, 2007), h.106.

${ }^{4}$ Ismail Saleh, Hukum dan Ekonomi (Jakarta: PT Gramedia Pustaka Utama, 1990), h.45.

5 Khoirul Hidayah, Hukum HKI (Hak Kekayaan Intelektual di Indonesia Kajian Undang-Undang \& Integrasi Islam) (Malang: UIN-Maliki Press, 2013), h. 23.

${ }^{6}$ Khoirul, Hukum HKI, h.9.
} 
Pada pasal 1 Undang-Undang No. 19 Tahun 2002 tentang Hak Cipta menyatakan bahwa: ${ }^{7}$

Pencipta adalah seseorang atau beberapa orang secara bersama-sama yang atas inspirasinya melahirkan suatu ciptaan berdasarkan kemampuan pikiran, imajinasi, kecakapan, ketrampilan, atau keahlian yang dituangkan ke dalam bentuk yang khas dan bersifat pribadi.

Ciptaan adalah hasil setiap karya pencipta yang menunjukan keasliannya dalam lapangan ilmu pengetahuan, seni, atau sastra.

Pemegang hak cipta adalah pencipta sebagai pemilik hak cipta, atau pihak yang menerima hak tersebut dari pencipta atau pihak lain yang menerima lebih lanjut hak dari pihak yang menerima hak tersebut.

Pengumuman adalah pembacaan, penyiaran, pameran, penjualan, pengedaran atau penyebaran, suatu ciptaan dengan menggunakan alat apapun, termasuk media internet, atau melakuakan dengan cara apapun sehingga suatu ciptaan dapat dibaca, didengar atau dilihat orang lain.

Perbanyakan adalah penambahan jumlah suatu ciptaan, baik secara keseluruhan maupun bagian yang sangat subtansial dengan menggunakan bahan-bahan yang sama ataupun tidak sama, termasuk mengalih wujudkan secara permanen atau temporer.

Penggolongan tersebut mengakibatkan tidak selamanya si pencipta berstatus sebagai pemegang hak cipta. Pada saat si pencipta telah mengalihkan semua hak cipta atas ciptaannya pada pihak lain, pencipta tidak lagi berstatus sebagai pemegang hak cipta yang tertinggal pada si pencipta hanyalah moral rights atau hak moral yang menghubungkan nama pencipta dengan ciptaan tersebut selamalamanya dimaksud dengan pemegang hak cipta adalah pencipta sebagai pemilik hak cipta, atau pihak yang menerima hak tersebut dari pencipta atau pihak lain yang menerima lebih lanjut hak dari pihak yang menerima hak tersebut, sebagaimana yang dimaksudkan oleh pasal 1 butir (4) Undang-Undang No. 19 Tahun 2002 tentang Hak Cipta. Undang-

\footnotetext{
${ }^{7}$ Undang-Undang No. 19 Tahun 2002 Tentang Hak Cipta.
}

Undang Hak Cipta juga mengenal konsep terjadinya pemilikan hak cipta berdasarkan suatu peristiwa hukum terjadinya pemilikan hak cipta berdasarkan suatu peristiwa hukum yang diatur dalam pasal 3 ayat (2) UndangUndang No. 19 Tahun 2002 tentang Hak Cipta, seperti pengalihan hak berdasarkan perjanjian, jual beli, pemberian hibah, wasiat, warisan, perjanjian tertulis dan sebab-sebab lain yang dibenarkan oleh peraturan perundang-undangan.

Adapun hak yang terkandung dalam Hak Cipta (Copyrights) adalah hak moral, hak yang melekat pada diri pencipta yaitu hak untuk selalu dicantumkan nama pencipta dalam setiap ciptaanya dan hak atas keutuhan ciptaanya, tidak dapat dihilangkan atau dihapus, meskipun hak cipta atau hak terkait telah dialihkan. ${ }^{8}$ Hak ekonomi adalah hak yang dimiliki oleh pencipta atau pemegang hak cipta untuk mendapat manfaat ekonomi dari penciptanya, atau hak mengizinkan atau melarang orang lain untuk menggunakan dan atau memperbanyak ciptaannya. ${ }^{9}$

Pelanggaran hak cipta pada dasarnya ada dua yaitu pelanggaran terhadap hak moral dan pelanggaran terhadap hak ekonomi pencipta. Pelanggaran hak ekonomi diatur di dalam pasal 72 Undang-Undang No. 19 Tahun 2002 tentang Hak Cipta. Pelanggaran yang dimaksud dalam pasal 72 Undang-Undang No. 19 Tahun 2002 tentang Hak Cipta dikategorikan sebagai tindak pidana sedangkan pelanggaran hak moral diatur dalam pasal 24 Undang-Undang No. 19 Tahun 2002 tentang Hak Cipta, dan pelanggaran yang dimaksud dapat dilakukan dengan gugatan perdata dan ganti rugi. Lembaga yang diberi kewenangan untuk menyelesaikan pekara pelanggaran hak ekonomi adalah pengadilan niaga. ${ }^{10}$

Pendaftaran ciptaan dalam pasal 37 Undang-Undang No. 19 Tahun 2002 tentang Hak Cipta menyatakan bahwa: ${ }^{11}$

\footnotetext{
${ }^{8}$ Khoirul hidayah, hukum HKI, h. 49-50.

${ }^{9}$ Endang Purwaningsih, Perkembangan Hukum Intellectual Property Right (Bogor: Ghalia Indonesia, 2005), h. 4-5.

${ }^{10}$ Khoirul, Hukum HKI, h. 59.

${ }^{11}$ Undang-Undang Hak Cipta No 19 Tahun 2002.
} 
Pendaftaran ciptaan dalam daftar umum ciptaan dilakukan atas permohonan yang diajukan oleh pencipta atau oleh pemegang hak cipta atau kuasa;

Permohonan diajukan kepada Direktorat Jenderal dengan surat rangkap 2 (dua) yang ditulis dalam Bahasa Indonesia dan disertai contoh ciptaan atau penggantinya dengan dikenai biaya;

Terhadap permohonan sebagaimana dimaksud pada ayat (1) Direktur Jenderal akan memberikan keputusan paling lama 9 (sembilan) bulan terhitung sejak tanggal diterimanya permohonan secara lengkap;

Kuasa sebagaimana dimaksud pada ayat (1) adalah konsultan yang terdaftar pada Direktorat Jenderal;

Ketentuan mengenai syarat-syarat dan tata cara untuk dapat diangkat dan terdaftar sebagai konsultan sebagaimana dimaksud pada ayat (4) diatur lebih lanjut dalam Peraturan Pemerintah;

Ketentuan lebih lanjut tentang tata cara permohonan ditetapkan dengan Keputusan Presiden.

Pada pasal 12 ayat (1) UndangUndang No. 19 Tahun 2002 tentang Hak Cipta. Ciptaan yang dilindungi adalah ciptaan dalam bidang ilmu pengetahuan, seni, sastra yang mencakup: ${ }^{12}$

(1) Buku, program computer, pamflet, perwajahan (lay uot) karya tulis yangdan semua hasil karya tulis lain;

(2) Ceramah, kuliah, pidato, dan ciptaan lain yang sejenis dengan itu;

(3) Alat peraga yang dibuat untuk kepentingan pendidikan dan ilmu pengetahuan;

(4) Lagu atau musik dengan atau tanpa teks;

(5) Drama atau drama musikal koreografi, pewayangan, pantonim;

(6) Seni rupa dalam segala bentuk seperti seni lukis, gambar, seni ukir, seni kaligrafi, seni pahat, seni patung, kolase, seni terapan yang berupa seni kerajinan tangan;

(7) Arsitektur;

(8) Peta;

(9) Seni batik;

(10) Fotografi;

\footnotetext{
${ }^{12}$ Undang-Undang No. 19 Tahun 2002.
}

(11) Sinematografi;

(12) Terjemahan, tafsir, saduran, bunga rampai, database, dan karya lain dari hasil pengalihwujudan.

Hak cipta dalam hukum Islam. hak berasal dari bahasa arab hâqq, secaraharfiah berarti "kepastian" atau "ketetapan", sebagaimana terdapat dalam Surat Yasin: $7 .{ }^{13}$

Artinya:" sesungguhnya telah pasti berlaku perkataan (ketentuan Allah) terhadap kebanyakan mereka, kerena mereka tidak beriman."

$$
\text { Al-milkiyyah atau al-milku }
$$

(kepemilikan, hak milik) adalah hubungan keterikatan antara seseorang dengan harta yang dikukuhkan dan dilegitimasi keabsahannya oleh syarak yang hubungan keterkaitan itu menjadikan harta tersebut hanya khusus untuknya dan ia berhak melakukan semua bentuk pentasharufan terhadap harta itu selagi tidak ada suatu hal yang menjadi penghalang dirinya dari melakukan pentasharufan. $^{15}$ Hak cipta sebagai Harta Mâliyah dalam pandangan para fuqaha bersendi kepada dua asas dan dua unsur yaitu 'ainiyah dan urf yang dimaksud dengan 'ainiyah ialah harta itu merupakan benda, ada wujudnya dalam kenyataan sedangkan yang dimaksud dengan urf adalah harta itu dipandang harta oleh manusia, baik oleh semua manusia, ataupun sebagian mereka dapat diberi atau tidak diberi sesuatu yang tidak berlaku demikian, tidaklah dipandang harta walaupun benda, seperti manusia yang merdeka, sepotong roti. Mâl yaitu harta ialah segala benda yang berharga yang bersifat materi yang beredar antara manusia. ${ }^{16}$ Terkait pelanggaran hak cipta bahwa dalam keputusan Fatwah MUI tahun 2005 tentang perlindungan hak kekayaan Intelektual mengutip pendapat dari Fathi al-Duraini yang mengatakan terdapat pendapat ulama tentang HKI, antara

\footnotetext{
13 Ghuffron A. Masadi, Fiqh Muamalah Konstektual (Jakarta: PT. Raja Grafindo Persada, 2002), h. 31.

${ }^{14}$ Qs. Yaasiin, (36): 7.

${ }^{15}$ Wahbah Az-Zuhaili, Fikih Islam Wa Adillatuhu, terj, Abdul Hasyyie al-Kattani dkk, Jilid V1, (Cet 1; Jakarta: Gema Insani, 2011), h. 449.

16 T.M. Hasbi Ash Shiddieqy, Pengantar Fikih Muamalah (Cet. IV; Jakarta: P.T. Bulan Bintang. 2001), h.142.
} 
lain. Mayoritas ulama dari kalangan mazhab Maliki, Syafi i dan Hambali berpendapat bahwa hak cipta atas ciptaan yang orisinil dan manfaat tergolong harta berharga sebagaimana benda jika boleh dimanfaatkan secara syara (hukum Islam). ${ }^{17}$ Adapun dalildalil syâr'î yang dapat dijadikan dasar melarang pelanggaran hak cipta dengan perbuatan-perbuatan tersebut di atas antara lain sebagai berikut: ${ }^{18}$

\section{Al-Qur'an Surat Al-Baqarah ayat 188}

Yang artinya :

“ janganlah sebagaimana kamu memakan harta sebagian yang lain dengan jalan yang bathil. ${ }^{19}$

\section{Metode Penelitian.}

Pada penelitian ini, peneliti langsung ke lapangan untuk mengamati serta mengumpulkan data-data yang memiliki peran utama dalam hasil penelitian, maka peneliti di sini menggunakan jenis penelitian hukum empiris. Hukum empiris bertujuan untuk mendukung perkembangan ilmu hukum, tidak cukup hanya dilakukan dengan melakukan studi mengenai sistem norma saja. Hukum yang pada kenyataannya dibuat dan diterapkan oleh manusia yang hidup dalam masyarakat. Artinya, keberadaan hukum tidak bisa dilepaskan dari keadaan social masyarakat serta prilaku manusia yang terkait dengan lembaga hukum tersebut. $^{20}$

Pada penelitian ini terkait perlindungan motif batik milik perorangan dalam kajian Undang-Undang No. 19 Tahun 2002 Tentang Hak Cipta dan Fatwa MUI maka peneliti menggunakan pendekatan penelitian yuridis sosiologis. Pendekatan yuridis sosiologis atau sering disebut sebagai penelitian hukum yang

\footnotetext{
${ }^{17}$ Keputusan Fatwa Majelis Ulama Indonesia, Nomor: 1/MUNAS VII/MUI/15/2005 Tentang Perlindungan Hak Kekayaan Intelektual (HKI), lihat Fathi al-Duraini, Haqq al-Ibtikar fi al-Fiqh al-Islami al-Muqaran, (Bairut: Mu`assasah al- Risalah, 1984), h. 20.

${ }^{18}$ Masjfuk, Masail Fiqhiyah Kapita, h. 213.

${ }^{19}$ Qs. Al-Baqarah:118

${ }^{20}$ Mukti faja ND,Yulianto Achmad, Dualisme Penelitian Hukum Normatif \& Empiris (Cet. 2; Yogyakarta: Pustaka Pelajar, 2013), h. 44.
}

sosiologis berdasarkan mazhab sociological jurisprudence adalah penelitian yang berbasis pada norma hukum normatif (peraturan perundang-undangan), tetapi bukan mengkaji mengenai sistem norma dalam aturan perundangan, namun mengamati bagaimana reaksi dan interaksi yang terjadi ketika sistem norma itu bekerja di dalam masyarakat. ${ }^{21}$ Metode penentuan subyek yang digunakan adalah purposive sampling yang disebut juga sampel bertujuan, artinya memilih sampel berdasarkan penelitian tertentu karena unsurunsur atau unit-unit yang dipilih dianggap mewakili populasi. ${ }^{22}$ Penelitian ini menggunakan dua jenis data kualitatif yaitu data primer dan data sekunder. Data primer atau data dasar adalah data yang diperoleh langsung dari masyarakat. ${ }^{23}$ Dalam hal penelitian ini mengambil penelitian secara langsung dengan wawancara kepada beberapa narasumber yaitu Sutini pemilik Diana Batik, Wiranto pemilik Elsa Batik, Achmad Aris pemilik UD. Risma Batik Prayungan, Hariyanto pemilik UD. Mega Spot, Pudji Rahayu pemilik Marelly Jaya dan Dinas Perindustrian dan Perdagangan Kab. Bojonegoro. Pengumpulan data dilakukan dengan dua cara yaitu dokumentasi dan wawancara. $^{24}$ Pada penelitian ini peneliti melakukan yaitu melalui tahapan pengolahan, edit atau editing, klasifikasi (classifaying), verifikasi (verifying) dan analisis (analyzing).

\section{Bentuk perlindungan yang dilakukan oleh pengrajin dan pemerintah daerah terhadap motif batik milik pengrajin perorangan di Bojonegoro}

Mendata dan mendokumentasikan motif-motif milik pengrajin batik.

\footnotetext{
${ }^{21}$ Mukti, Dualisme Penelitian, h.47.

22 Bahder Johan Nasution. Metode Penelitian Ilmu Hukum (Bandung: CV. Bandar Maju, 2008). h.159-16.

${ }^{23}$ Soekanto, Soerjono \& Sri Mamudji, Penelitian Hukum Normatif Suatu Tinjauan Singkat, (Jakarta: PT. Raja Grafindo Persada, 2006), h.12.

${ }^{24}$ S. Nasution dan M. Thomas, Buku Penuntun Membuat Tesis, Skripsi, Disertasi, dan Makalah (Bandung: Jemmars, 1988), h.58.
} 
Pemerintah melakukan pendataan kepada motif batik milik pengrajin perorangan dengan tujuan agar tidak ditiru oleh pengrajin lain. Pemerintah di sini membuka pendaftaran bagi pengrajin batik yang memiliki motif hasil karya sendiri bukan tiruan dan pengembangan dari 14 motif batik Jenegoroan serta motif milik pengrajin lain.

Pemberian sanki kepada pengrajin yang terbukti menyontoh motif milik pengrajin batik lain .

Pemberian sanksi ini diberikan kepada pengrajin yang terbukti meniru motif batik milik pengrajin lain tanpa izin dari pemilik motif. Pengrajin akan diberi teguran jika teguran tidak dihiraukan maka izin usaha akan dicabut.

Memberi Info kepada para pengrajin batik mengenai hak cipta dan perlindungannya.

Pemerintah di sini mengadakan pertemuan kepada para pengrajin di Kab. Bojonegoro setiap satu bulan sekali. Pada pertemuan ini pemerintah mengumpulkan para pengrajin batik di Kab. Bojonegoro selain pemerintah memberikan info mengenai hak cipta motif batik dan perlindungannya yang di akui oleh negara dan secara resmi yaitu dengan mendaftarkan hasil karya motif batiknya ke DJHKI selain itu juga membicarakan keluhankeluhan yang dialami oleh pengrajin batik .

Menghimbau para pengrajin batik untuk mendaftarkan motif batik karya pengrajin sendiri dan nama unit usahanya.

Pada pendaftaran ini maka pemerintah daerah menyerahkan kepada Dinas Perindustrian dan Perdagangan Kab. Bojonegoro (Disprindag) untuk mengahimbau para pengrajin batik di Bojonegoro untuk mendaftarkan hasil karya motif batik dan nama unit usaha agar mudah mengontrol siapa-siapa saja yang telah memiliki motif batik karya sendiri serta untuk mengawasi para pengrajin batik di kab. Bojonegoro jika melakukan pelanggaran dengan mencontoh, memperbanyak dan menjual secara umum motif batik milik pengrajin lain yang tanpa sepengetahuan pemerintah daerah Kab. Bojonegoro.

Pelarangan menggunakan batik printing.
Pemerintah menghimbau kepada pengrajin batik di Bojonegoro untuk tidak menggunakan batik printing. Terkait dengan perlindungan pemkab. Bojonegoro untuk melindungi karya pencipta motif batik perorangan maka terdapat prosedur proses pendaftaran ke Disprindag Kab. Bojonegoro.

\section{Bentuk Perlindungan Hukum Terhadap Motif Batik Milik Pengrajin Perorangan Di Bojonegoro Ditinjau Undang- Undang No. 19 Tahun 2002 Tentang Hak Cipta Dan Fatwa MUI.}

Perlindungan hukum pada hasil ciptaan atau hak cipta motif batik menurut penulis sangat penting sekali guna melindungi hak milik pencipta atas ciptaanya. Pemerintah Indonesia dalam memberikan perlindungan hak cipta terutama batik maka pemerintah mengeluarkan lah Undang-Undang No. 19 Tahun 2002 dan Fatwa MUI guna memberikan perlindungan yang utuh bahwa pengambilan hak milik orang lain untuk memperoleh keuntungan dalam undang-undang dan hukum Islam terkait Fatwa MUI di larang. Pada pembahasan kali ini peneliti akan memaparkan terkait perlindungan hak cipta pada UndangUndang No. 19 Tahun 2002 Tentang Hak Cipta dan Fatwa MUI

\section{Perlindungan Motif Batik Milik Pengrajin Perorangan di Bojonegoro Menurut Undang-Undang No. 19 Tahun 2002 Tentang Hak Cipta.}

Pemerintah untuk memberikan bentuk perlindungan terkait hak cipta terutama batik karena hak cipta motif batik merupakan salah satu hak milik dari hasil jerih payah untuk menciptakan sebuah ide untuk menjadi sebuah bentuk karya yang indah dan memiliki nilai. Hak cipta merupakan salah satu hak kekayaan intelektual yang merupakan hasil dari daya fikir manusia untuk membuat dan menciptakan sebuah karya atau seni. Hak cipta yang dilindungi adalah ide yang telah berwujud dan asli oleh karena itu undang-undang melindungi hak cipta terutama motif batik yang merupakan salah satu ciptaan yang dilindungi pemerintah untuk melindungi hak karya seseorang itu maka pemerintah mengeluarkan undangundang yang berlaku saat ini yaitu UndangUndang Hak Cipta No. 12 Tahun 2002 Tentang Hak Cipta. 
Pada pasal 1 ayat (3) Undang-Undang Hak Cipta No. 12 Tahun 2002 Tentang Hak Cipta. $^{25}$

Ciptaan adalah hasil setiap karya Pencipta yang menunjukkan keasliannya dalam lapangan ilmu pengetahuan, seni, atau sastra.

Pada motif batik merupakan salah satu bentuk seni atau ciptaan yang dilindungi oleh Undang-Undang No. 19 Tahun 2002 Tentang Hak Cipta. Pada Pada pasal 12 ayat (1) Undang-Undang No. 19 Tahun 2002 tentang Hak Cipta. satu huruf i, menyebutkan bahwa.

Ciptaan yang dilindungi adalah ciptaan dalam bidang ilmu pengetahuan, seni, sastra yang mencakup: $:^{26}$

(1) Buku, program computer, pamflet, perwajahan (lay uot) karya tulis yangdan semua hasil karya tulis lain.

(2) Ceramah, kuliah, pidato, dan ciptaan lain yang sejenis dengan itu.

(3) Alat peraga yang dibuat untuk kepentingan pendidikan dan ilmu pengetahuan.

(4) Lagu atau musik dengan atau tanpa teks.

(5) Drama atau drama musikal koreografi, pewayangan, pantonim

(6) Seni rupa dalam segala bentuk seperti seni lukis, gambar, seni ukir, seni kaligrafi, seni pahat, seni patung, kolase, seni terapan yang berupa seni kerajinan tangan.

(7) Arsitektur.

(8) Peta.

(9) Seni batik.

(10) Fotografi.

(11) Sinematografi.

(12) Terjemahan, tafsir, saduran, bunga rampai, database, dan karya lain dari hasil pengalihwujudan.

Seni batik merupakan ciptaan yang dilindungi. Perlindungan motif batik atau seni batik merupakan ciptaan yang dilindungi dalam kategori mengumumkan, memperbanyak, ciptaan yang tidak meminta izin kepada pencipta. Pada Undang-Undang No. 19 Tahun

\footnotetext{
${ }^{25}$ Pada pasal 3 ayat (3) No. 12 Tahun 2002 Tentang Hak Cipta.

${ }^{26}$ Undang-Undang No. 19 Tahun 2002.
}

2002 terkait perlindungan motif batik bahwa undang-undang melindungi hak moral atau hak yang selalu dicantumkan nama pencipta dalam setiap karyanya yang akan di perbanyak atau di contoh dan hak ekonomi pencipta yaitu hak yang dimana pencipta mendapatkan manfaat ekonominya dari hasil karya atau ciptaanya.

Pada pasal 2 ayat (1) Undang-Undang No. 19 Tahun 2002 Tentang Hak Cipta mengatakan bahwa :

Hak Cipta merupakan hak eksklusif bagi Pencipta atau Pemegang Hak Cipta untuk mengumumkan atau memperbanyak Ciptaannya, yang timbul secara otomatis setelah suatu ciptaan dilahirkan tanpa mengurangi pembatasan menurut peraturan perundang- undangan yang berlaku. ${ }^{27}$

Pada pelanggaran hak cipta motif batik baik itu memperbanyak, mengumumkan, mengcopy dan menjual secara umum untuk memperoleh keuntungan pribadi menurut pasal 72 ayat (1) Undang-Undang No. 19 Tahun 2002 Tentang Hak Cipta akan dikenakan pidana penjara paling singkat 1 (satu) bulan dan atau denda paling sedikit Rp. 1.000.000 satu juta rupiah dan denda paling lama 7 (tujuh) tahun dan atau denda paling banyak Rp. 5.000.000.000,00 (lima miliar rupiah) dan pada ayat (2) juga dijelaskan bahwa jika ada pengrajin batik yang mengedarkan dan menjual kepada umum motif batik hasil pelanggaran hak cipta maka akan dikenakan dengan pidana penjara paling lama 5 (lima) tahun dan atau denda paling banyak Rp. 500.000,00 (lima ratus juta rupiah).

Pada penjelasan di atas untuk memperoleh perlindungan motif batik maka para pengrajin harus mendaftarkan karyanya ke DJHKI sesuai pada ketentuan pasal 37 UU No. 19 Tahun 2002 Tentang Hak Cipta menyatakan bahwa: ${ }^{28}$

(1) Pendaftaran ciptaan dalam daftar umum ciptaan dilakukan atas permohonan yang diajukan oleh pencipta atau oleh

\footnotetext{
${ }^{27}$ Pasal 2 ayat (1) Undang-Undang No. 19 Tahun 2002 Tentang Hak Cipta.

${ }^{28}$ Undang-Undang No 19 Tahun 2002.
} 
pemegang hak cipta atau kuasa.

(2) Permohonan diajukan kepada Direktorat Jenderal dengan surat rangkap 2 (dua) yang ditulis dalam Bahasa Indonesia dan disertai contoh ciptaan atau penggantinya dengan dikenai biaya.

(3) Terhadap permohonan sebagaimana dimaksud pada ayat (1) Direktur Jenderal akan memberikan keputusan paling lama 9 (sembilan) bulan terhitung sejak tanggal diterimanya permohonan secara lengkap.

(4) Kuasa sebagaimana dimaksud pada ayat (1) adalah konsultan yang terdaftar pada Direktorat Jenderal.

(5) Ketentuan mengenai syarat-syarat dan tata cara untuk dapat diangkat dan terdaftar sebagai konsultan sebagaimana dimaksud pada ayat (4) diatur lebih lanjut dalam Peraturan Pemerintah.

(6) Ketentuan lebih lanjut tentang tata cara permohonan ditetapkan dengan Keputusan Presiden.

Pada perlindungan motif batik di dalam UU No. 19 Tahun 2002 Tentang Hak Cipta bahwa, Pencipta atau pemegang hak cipta harus melakukan pendaftaran ke Direktorat Jendral Hak Kekayaan Intelektual Kementerian Hukum dan Hak Asasi Manusia R.I (DJHKI) sebagai bukti utama yang sah dan resmi jika terjadi pelanggaran atas karya ciptaannya yang dicontoh dan di perjualbelikan secara umum maka dengan bukti pendaftaran ciptaan motif batik ke Direktorat Jendral Hak Kekayaan Intelektual Kementerian Hukum dan Hak Asasi Manusia R.I (DJHKI) bisa melakukan gugatan perdata atau ganti rugi jika melanggar hak moral pencipta jika dalam penggunaan motif batik tidak menyantumkan nama pencipta atau pencipta motif batik tidak di akui sebagai pemilik hasil ciptaan tersebut, sebagaimana pada pasal 24 UU. No 19 Tahun 2002 Tentang Hak Cipta yang menyebutkan bahwa.

(1) Pencipta atau ahli warisnya berhak menuntut Pemegang Hak Cipta supaya nama Pencipta tetap dicantumkan dalam Ciptaannya.

(2) Suatu Ciptaan tidak boleh diubah walaupun Hak Ciptanya telah diserahkan kepada pihak lain, kecuali dengan persetujuan Pencipta atau dengan persetujuan ahli warisnya dalam hal Pencipta telah meninggal dunia.

(3) Ketentuan sebagaimana dimaksud pada ayat (2) berlaku juga terhadap perubahan judul dan anak judul Ciptaan, pencantuman dan perubahan nama atau nama samaran Pencipta.

(4) Pencipta tetap berhak mengadakan perubahan pada Ciptaannya sesuai dengan kepatutan dalam masyarakat. $^{29}$

Pada pelanggaran hak moral dapat di ajukan gugatan perdata atau ganti rugi serta bisa masuk pada ranah tindakan pidana jika melanggar hak ekonomi pencipta atau pemegang hak cipta yaitu hak untuk mendapat manfaat ekonomi yang dimana dapat di jerat dengan pasal 72 UU No. 19 Tahun 2002 Tentang Hak Cipta yang telah peneliti jelaskan di atas.

Pada penjelasan pada UndangUndang No. 19 Tahun 2002 Tentang Hak Cipta bahwa terkait perolehan atau perlindungan hukum motif batik menurut UndangUndang No. 19 Tahun 2002 Tentang Hak Cipta harus sesuai dengan ketentuan pada pasal 37 UU No. 19 Tahun 2002 Tentang Hak Cipta seperti yang peneliti jelaskan di atas.

Terkait perlindungan motif batik menurut UU No. 19 Tahun 2002 Tentang Hak Cipta. Pada penelitian yang peneliti lakukan bahwa pengrajin batik di kab. Bojonegoro belum keseluruhan melakukan pendaftaran sesuai dengan ketentuan pada UU No. 19 Tahun 2002 Tentang Hak Cipta.

Pada hasil penelitian yang telah peneliti lakukan bahwa dari lima narasumber yang peneliti ambil yaitu Diana Batik, Elsa Batik, UD. Risma Prayungan, UD. Mega Spot dan Marelly Batik.

Pada lima narasumber yang peneliti wawancara ada beberapa pengrajin yang belum memiliki motif hasil karyanya sendiri. Para pengrajin batik ini biasanya menggunakan 14 motif Batik Jenegoroan yang hak ciptanya dipegang oleh pemerintah Kab. Bojonegoro. Pengrajin bebas menggunakan, memperbanyak, menggabungkan dan mengembangkan sendiri dari 14 motif Batik Jenegoroan tersebut agar terlihat berbeda dari aslinya hal tersebut

\footnotetext{
${ }^{29}$ Pasal 24 UU. No. 19 Tahun 2002 Tentang Hak Cipta
} 
diperbolehkan untuk diperjualbelikan. Pengrajin batik di kab. Bojonegoro banyak

Pada hasil wawancara yang dilakukan peneliti dengan narasumber bahwa yang belum melakukan pendaftaran hak cipta dan yang sudah melakukan pendaftaran hak cipta dalam data tabel di atas dapat disimpulkan bahwa dari lima sampel didapatkan 2 atau 40\% yang sudah melakukan pendaftaran hak cipta pada Direktorat Jendral Hak Kekayaan Intelektual Kementerian Hukum dan Hak Asasi Manusia menggunakan motif-motif gabungan serta pengembangan dari 14 motif Batik Jenegoroan.

dan 3 atau $60 \%$ belum mendaftar. Adapun hasil wawancara yang peneliti lakukan dengan para pengrajin batik akan peneliti uraikan dalam bentuk tabel seperti di bawah ini.

Tabel 2: Data Pengrajin Batik yang Mendaftarkan Hak Cipta Motif Batik

\begin{tabular}{|c|c|c|c|c|c|c|}
\hline No & $\begin{array}{c}\text { Nama } \\
\text { Pengrajin }\end{array}$ & $\begin{array}{r}\text { Jumlal } \\
\text { Motif Mi }\end{array}$ & & Terdaftar & $\begin{array}{c}\text { Belum } \\
\text { Terdaftar }\end{array}$ & Alasan \\
\hline 1. & $\begin{array}{l}\text { Sutini } \\
\text { (Diana Batik) }\end{array}$ & $\begin{array}{l}\text { Punya } \\
\text { (Motif Daerah) }\end{array}$ & & & $\checkmark$ & Tidak Penting \\
\hline 2 & $\begin{array}{l}\text { Wiratno } \\
\text { (Ellsa Batik) }\end{array}$ & $\begin{array}{l}28 \text { Motif dan } \\
\text { Pengembangan } \\
\text { daerah }\end{array}$ & motif & & $\checkmark$ & Tidak Penting \\
\hline 3. & $\begin{array}{l}\text { Achmat Aris, } \\
\text { (UD. Risma } \\
\text { Batik Prayungan) }\end{array}$ & $\begin{array}{l}3 \text { Motif dan } \\
\text { Pengembangan } \\
\text { daerah }\end{array}$ & motif & $\checkmark$ & & Penting \\
\hline 4. & $\begin{array}{l}\text { Hariyanto } \\
\text { (UD Mega Spot) }\end{array}$ & $\begin{array}{l}2 \text { Motif dan } \\
\text { Pengembangan } \\
\text { daerah }\end{array}$ & motif & & $\checkmark$ & Tidak Penting \\
\hline 5. & $\begin{array}{l}\text { Pudji Rahayu, } \\
\text { (Marelly Jaya) }\end{array}$ & $\begin{array}{l}8 \text { Motif dan } \\
\text { Pengembangan } \\
\text { daerah }\end{array}$ & motif & $\checkmark$ & & Penting \\
\hline
\end{tabular}

Mendaftarkan Hak Cipta Motif Batik. ${ }^{30}$

\section{Perlindungan Hak Cipta Menurut Fatwa MUI}

Pada hukum islam dikenal dengan almilkiyyah adalah hubungan keterikatan antara seseorang dengan harta pada Fatwa MUI terdapat larangan terkait pengambilan hak orang lain yang bukan haknya atau biasa disebut dengan pelanggaran hak cipta terkait mengcopy, memperbanyak, membajak dan lain sebagainya untuk mencari keuntungan pribadi. Maraknya pelanggaran hak cipta di Indonesia yang merugikan bagi pencipta atau penemu maka di sini MUI sebagai wadah musyawarah ulama, zu'ama dan cendekiawan Islam di Indonesia oleh karena itu MUI mengeluarkan

${ }^{30}$ Wawancara (Bojonegoro, 05-12 Januari 2014). fatwah terkait hak cipta atau kaitannya dengan HKI Fatwa No.1/MUNASVII/MUI/15/2005 tentang Perlindungan Hak Kekayaan Intelektual. Pada Fatwa MUI HKI atau hak kekayaan intelektual yang merupakan salah satu hak cipta yang dipandang sebagai salah satu huquq mâliyah atauhak kekayaan yang memperoleh perlindungan hukum sebagaimana dengan harta atau mâl.

Pada Al-Qur'an Surat Al-Baqarah ayat 188 yang artinya : "janganlah sebagaimana kamu memakan harta sebagian yang lain de-ngan jalan yang bâthil. ${ }^{31}$,"

Pada ayat di atas menurut peneliti bahwa Islam melarang memakan harta orang lain dengan jalan yang haram. Hukum Islam sangat menghargai hak milik orang lain,

\footnotetext{
${ }^{31}$ Qs. Al-Baqarah:118
} 
terutama harta serta Islam melarang manusia mencari keuntungan dengan jalan yang bâthil yang dimana bisa merugikan hak orang lain menjual, mencontoh, dan mengedarkan motif milik pengrajin lain tanpa sepengetahuan pemilik motif batik adalah perbuatan yang di larang Allah yang di mana jika melakukan penyontohan motif batik milik orang lain tanpa izin pemilik kemudian menjual untuk mendapat keuntungan secara pribadi termasuk kategori pencurian yang di mana mencuri dapat dikenakan ganti rugi atau ta'zir yang menurut Wahbah Az-Zuhaili menjelaskan terkait ta'zir bahwa beliau mengatakan bahwa ta'zir adalah hukuman yang bentuk dan ukurannya tidak ditentukan oleh syara', akan tetapi syara' memasrahkannya kepada kebijakan negara untuk menjatuhkan bentuk hukuman yang menurutnya sesuai dengan kejahatan yang dilakukan dan bisa memberikan efek jera. Mayoritas bentuk hukuman yang terdapat dalam undang-undang hukum positif adalah masuk kategori hukuman $t a$ 'zir. ${ }^{32}$

Terkait dengan pencontohan motif batik untuk dijual guna memperoleh keuntungan secara pribadi dapat di kenakan ta'zir yaitu Undang-Undang Hak Cipta No. 19 Tahun 2002 Tentang Hak Cipta yang merupakan bagian dari kebijakan negara dan termasuk yang bentuk hukumannya dalam kategori penjara atau denda tergantung besar kecilnya pelanggaran dan kerugian yang dialami oleh pencipta.

Tabel 3: Persamaan perlindungan hak cipta motif batik menurut Undang-Undang No. 19 tahun 2002 tentang Hak Cipta dan Fatwa MUI

\section{PERBANDINGAN PERLINDUNGAN HAK CIPTA Fatwa MUI dan}

UU NOMOR 19 TAHUN 2002.

Persamaan Perlindungan Undang-Undang No. 19 Tahun 2002 Tentang Hak

Cipta dan Hukum Islam (Fatwa MUI)

No Fatwa MUI UU Nomor 19 Tahun

\footnotetext{
${ }^{32}$ Wahbah, Fiqih Islam, Jilid 4, h. 256.
}

2002

1 Hak cipta motif Hak Kekayaan batik merupakan disebut sebagai Hak hak milik (al- Kekayaan Intelektual milkiyyah) dan (HKI) dalam UUHC. tergolong hak kekayaan (huquq mâliyah)

2 Hak Cipta bagi Hak cipta bagi pencipta menurut pencipta tertuang hukum Islam dalam Pasal 1 ayat memiliki hak (1) UU No. 19 kepemilikan Tahun 2002 Tentang sempurna Hak Cipta disebut sebagai hak eksklusif atau hak tunggal

\section{Terdapat \\ Terdapat} perlindungan hukum dalam hak cipta atas motif batik merupakan keterkaitan antara orang dengan harta (almilkiyyah) perlindungan hukum dalam hak cipta atas motif batik merupakan keterkaitan antara orang dengan harta (al-milkiyyah) dan memiliki nilai ekonomi

4 Hak cipta atas Pasal 3 ayat (1) dan motif batik dapat (2) UU No. 19 tahun dijadikan obyek 2002 tentang Hak akad baik akad Cipta bahwa obyek komersial maupun hak cipta merupakan komersial. non benda bergerak dan dapat dialihkan.

\begin{tabular}{|c|c|c|}
\hline & $\begin{array}{l}\text { Menurut Fatwa } \\
\text { MUI. Bahwa hak } \\
\text { cipta motif batik } \\
\text { bisa dialihkan } \\
\text { kepemilikan } \\
\text { melalui jual beli, } \\
\text { pewarisan, dan } \\
\text { wasiat. }\end{array}$ & $\begin{array}{l}\text { Menurut UUHC } \\
\text { bahwa hak cipta } \\
\text { motif batik bisa } \\
\text { dialihkan } \\
\text { kepemilikannya, } \\
\text { Pasal } 3 \text { ayat (2) }\end{array}$ \\
\hline & $\begin{array}{l}\text { Tujuan } \\
\text { perlindungan hak } \\
\text { cipta menurut } \\
\text { Fatwa MUI } \\
\text { bertujuan } \\
\text { melindungi hak } \\
\text { pencipta atas hasil }\end{array}$ & $\begin{array}{l}\text { Tujuan perlindungan } \\
\text { hak cipta dalam } \\
\text { UUHC bertujuan } \\
\text { melindungi hak } \\
\text { pencipta atas hasil } \\
\text { ciptaannya agar tidak } \\
\text { di manfaat oleh }\end{array}$ \\
\hline
\end{tabular}


ciptaannya agar orang lain untuk

tidak di manfaat mencari keuntungan

oleh orang lain secara pribadi serta

untuk mencari tidak merugikan hak-

keuntungan hak orang lain.

secara pribadi

serta tidak

merugikan hak-

hak orang lain. melindungi ide yang berwujud. Pada penelitian selanjutnya peneliti akan memaparkan terkait perbedaan perlindungan hak cipta motif batik Undang-Undang No. 19 Tahun 2002 Tentang

Hak Cipta dan Fatwa MUI. Pada tabel di bawah ini akan peneliti uraikan untuk mempermudah pembaca.

Pada data di atas bahwa terdapat persamaan ketentuan pada Undang-Undang No. 19 Tahun

2002 Tentang Hak Cipta dan Fatwa MUI terkait perlindungan hak cipta. Hak cipta hanya

Tabel 4: Perbedaan perlindungan hak cipta morif batik menurut Undang-Undang No. 19 Tahun 2002 tentang Hak Cipta

\begin{tabular}{|c|c|c|c|}
\hline No & Persoalan & $\begin{array}{l}\text { Undang-Undang No. } 19 \text { Tahun } \\
2002 \text { tentang Hak Cipta }\end{array}$ & Fatwa MUI \\
\hline 1. & $\begin{array}{l}\text { Subyek hak } \\
\text { cipta }\end{array}$ & $\begin{array}{l}\text { UUHC subyek hak cipta terdiri } \\
\text { dari } 2 \text { pencipta dan pemegang hak } \\
\text { cipta yang terdiri dari pemilik hak } \\
\text { cipta (pencipta) dan pihak yang } \\
\text { memperoleh hak cipta dari } \\
\text { pencipta.(pemegang hak cipta). }\end{array}$ & $\begin{array}{l}\text { Subyek akad atau orang yang } \\
\text { berakad hanya pencipta . }\end{array}$ \\
\hline 2. & $\begin{array}{l}\text { Sanski atau } \\
\text { hukuman yang } \\
\text { di terapkan }\end{array}$ & $\begin{array}{l}\text { Besar kecilnya pelanggaran atau } \\
\text { kejahatan yang dilakukan sudah } \\
\text { di atur dan ditentukan sanksinya } \\
\text { yaitu pidana dan denda besar } \\
\text { kecilnya hukuman telah di } \\
\text { cantumkan pada pasal } 72\end{array}$ & $\begin{array}{l}\text { Ganti rugi yang besar kecilnya ganti } \\
\text { rugi belum di tetapkan. }\end{array}$ \\
\hline 3. & $\begin{array}{l}\text { Bentuk } \\
\text { Pelanggaran }\end{array}$ & $\begin{array}{l}\text { Pada UUHC bentuk } \\
\text { pelanggaranya bermacam-macam } \\
\text { diantaranya mengumumkan, } \\
\text { memperbanyak ciptaan, } \\
\text { mengedarkan dan lain-lain }\end{array}$ & $\begin{array}{l}\text { Dalam hukum Islam atau Fatwa MUI } \\
\text { bentuk pelanggara berupa pencurian }\end{array}$ \\
\hline 4. & $\begin{array}{l}\text { Syarat } \\
\text { perolehan } \\
\text { perlindungan } \\
\text { hukum secara } \\
\text { resmi dan } \\
\text { penuh. }\end{array}$ & $\begin{array}{l}\text { Pada UUHC harus melalui } \\
\text { pendaftaran Ke DJHKI sebagai } \\
\text { bukti resmi bahwa ciptaanya } \\
\text { memperoleh perlindungan hak } \\
\text { cipta secara keseluruhan dan } \\
\text { diakui oleh Negara. }\end{array}$ & $\begin{array}{l}\text { Pada ketentuan hukum Islam pada } \\
\text { Fatwa MUI tidak ada ketentuan } \\
\text { harus yang mengharuskan } \\
\text { mendaftarkan ciptaanya ke DJHKI } \\
\text { secara hukum Islam ciptaan yang } \\
\text { merupakan hasil daya fikir manusia } \\
\text { sendiri, maka memperoleh } \\
\text { perlindungan hukum Islam secara } \\
\text { keseluruhan dan hukum nya haram } \\
\text { jika mengambil atau menggunakan } \\
\text { hak orang lain untuk kepentingan } \\
\text { mencari keuntungan secara pribadi. }\end{array}$ \\
\hline
\end{tabular}




\section{DAFTAR PUSTAKA}

A. Masadi, Ghuffron. Fiqh Muamalahn Konstektual. Jakarta: PT. Raja Grafindo Persada, 2002.

Az-Zuhaili, Wahbah. Fikih Islam Wa Adillatuhu. Terjemahan. Jilid 1V. Cet 1. Jakarta: Gema Insani, 2011.

Hasbi Ash-Shiddeqy, Tengku Muhammad. Pengantar Fikih Muamalah. Cet.IV. Jakarta: PT. Bulan Bintang, 2001.

Hidayah, Khoirul. Hukum Hak Kekayaan Intelektual di Indonesia Kajian Undang-Undang \& Integrasi Islam. Malang: UIN-Maliki Press, 2013.

Nasution, Bahder Johan. Metode Penelitian Ilmu Hukum. Bandung: CV. Bandar Maju, 2008.
Nasution S. \& M. Thomas. Buku Penuntun Membuat Tesis, Skripsi, Disertasi, dan Makalah. Bandung: Jemmars, 1988.

Purwaningsih, Endang. Perkembangan Hukum Intellectual Property Right. Bogor: Ghalia Indonesia, 2005.

Saleh, Ismail. Hukum dan Ekonomi. Jakarta: PT Gramedia Pustaka Utama, 1990.

Susilowati, Etty. Kontrak Alih Teknologi pada Industri Manufaktur. Yogyakarta: Genta Press, 2007.

Zuhdi, Masjfuk. Masail Fiqhiyah Kapita Selekta Hukum Islam. Edisi I. Cet I. Jakarta: CV. Haji Masagung, 1994.

Undang-Undang Nomor 19 Tahun 2002 Tentang Hak Cipta 